\section{Influence of Nitrogen Rate, Fertilizer Type, and Application Method on Cabbage Yield and Nutrient Concentrations}

\author{
Timothy Coolong ${ }^{1}$, Kate Cassity-Duffey ${ }^{1}$, and \\ Andre Luiz Biscaia Ribeiro da Silva ${ }^{2}$
}

ADDITIONAL INDEX WORDs. bare ground, Brassica olevacea var. capitata, calcium nitrate, granular fertilizer, harvest delay

SuMMARY. Georgia is a leading fresh market cabbage (Brassica olevacea var. capitata) producer. Current recommendations for bare-ground cabbage grown in the Coastal Plain of Georgia indicate 175 to $225 \mathrm{lb} /$ acre nitrogen $(\mathrm{N})$.

Approximately one-third of $\mathrm{N}$ fertilizer is recommended at planting, with two or three additional side-dress applications during the season. Growers have begun banding liquid fertilizer between four and six times during the season to reduce $\mathrm{N}$ leaching and enhance productivity. To determine the validity of current recommendations as well as the efficacy of applying periodic liquid fertilizer throughout the growing season, field experiments were conducted in Tifton, GA in Fall 2016 and 2017 with the cabbage cultivar Cheers. Fertilizer $\mathbf{N}$ rates were $175,200,225$, and $250 \mathrm{lb} /$ acre $\mathrm{N}$ applied using equivalent preplant fertilizer $(50 \mathrm{lb} /$ acre $\mathrm{N})$ with two posttransplant applications of a granular fertilizer $(27-0 \mathrm{P}-0 \mathrm{~K}-5 \mathrm{Ca})$ or six applications of a liquid fertilizer $(9 \mathrm{~N}-0 \mathrm{P}-0 \mathrm{~K}-11 \mathrm{Ca})$. A factorial, randomized, complete block design was used. There were no interactions among fertilizer program, $\mathrm{N}$ rate, or year for cabbage yield or nutrient concentrations. Total yield was unaffected by the $\mathrm{N}$ rate. However, plants fertilized with the lowest $N$ rate $(175 \mathrm{lb} /$ acre $N)$ had the lowest yields from the first two harvests compared with the other $\mathrm{N}$ rates. Nutrient concentrations were affected by year, with 2017 having greater concentrations of most macronutrients compared with 2016. In conclusion, the application of 175 $\mathrm{lb} /$ acre $\mathrm{N}$ led to a potential delay in harvest, but all other $\mathrm{N}$ rates were equal.

The application method did not impact yield or earliness, suggesting that current recommendations for fertilizer applications after planting cabbage in Georgia are adequate.

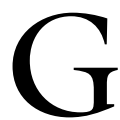
eorgia produced nearly 6000 acres of cabbage (Brassica oleracea var. capitata) valued at $\approx \$ 52$ million in 2019 (Stubbs, $2020)$. Georgia is a leading fresh market cabbage-producing state in the United States, and most of the crop is grown on sandy soils in the Coastal Plain of southern Georgia, which are prone to leaching nutrients such as $\mathrm{N}$ (Delgado, 2002; Scholberg et al.,

Received for publication 29 Oct. 2021. Accepted for publication 3 Dec. 2021

Published online 4 February 2022

${ }^{1}$ Department of Horticulture, The University of Georgia, 1111 Miller Plant Sciences, Athens, GA 30602

${ }^{2}$ Department of Horticulture, Auburn University, 124 Funchess Hall, Auburn, AL 36849

Funding for this research was provided by the Geor gia Commodity Commission for Vegetables.

T.C. is the corresponding author. E-mail: tcoolong@uga.edu.

This is an open access article distributed under the CC BY-NC-ND license (https://creativecommons. org/licenses/by-nc-nd/4.0/).

https://doi.org/10.21273/HORTTECH04982-21
2013). Frequent rainfall events in the subtropical environment of the southeastern United States can further exacerbate nitrate leaching. Current $\mathrm{N}$ fertilizer recommendations for the Coastal Plain of Georgia indicate the application of 175 to $225 \mathrm{lb} /$ acre N for bare-ground cabbage production using overhead irrigation (Kissel and Sonon, 2008). It is recommended that one-fourth to one-third of total fertilizer should be applied preplant, with the remaining applied in one to three side-dress applications after planting. da Silva et al. (2020a) reported no difference in the total yield of cabbage grown in the loamy sand soils of Georgia when using 170 to 280 $\mathrm{lb} /$ acre N. In that study, fertilizer applications were split between preplant and three posttransplant applications. In Ontario, Canada, cabbage yields have been maximized with $237 \mathrm{lb} /$ acre $\mathrm{N}$ in a bare-ground production system (Westerveld et al., 2003). However, research conducted in Florida using plasticulture systems have shown increased yields with $\mathrm{N}$ application rates more than $357 \mathrm{lb} /$ acre $\mathrm{N}$ for high-population (31,376 plants/acre) plantings (Barrett et al., 2018). Typically, fertilizer applications in plasticulture systems are more frequent and use a highly soluble $\mathrm{N}$ source compared with bareground systems (Lamont, 1993). Recently, some growers in southern Georgia have begun splitting posttransplant $\mathrm{N}$ into several applications using liquid fertilizers banded adjacent to planted rows (J. Kichler, personal communication) in an effort to reduce $\mathrm{N}$ losses (Hartz, 2006) and improve yields in a bare-ground production system.

Prior research has suggested that splitting fertilizer into multiple applications throughout crop development may provide no yield benefit compared with a single $\mathrm{N}$ application at planting in high clay content soils (Everaarts, 1993). Salo et al. (2002) reported that fertigation with soluble nutrients did not improve cabbage yield or nutrient uptake compared with broadcast applications of granular fertilizer using a drip irrigation system. Furthermore, multiple applications of liquid fertilizers may increase labor and input costs for growers (Fonsah, 2021). In contrast, frequent but small applications of fertilizer nutrients to many vegetables grown in coarse-textured soils have been shown to reduce leaching, increase nutrient use efficiency (NUE), and enhance yields (Hartz, 2006). Multiple applications

\begin{tabular}{llll}
\hline $\begin{array}{l}\text { Units } \\
\text { To convert U.S. to SI, } \\
\text { multiply by }\end{array}$ & U.S. unit & SI unit & $\begin{array}{l}\text { To convert SI to U.S., } \\
\text { multiply by }\end{array}$ \\
\hline 0.4047 & $\mathrm{acre}(\mathrm{s})$ & $\mathrm{ha}$ & 2.4711 \\
0.3048 & $\mathrm{ft}$ & $\mathrm{m}$ & 3.2808 \\
2.54 & inch(es) & $\mathrm{cm}$ & 0.3937 \\
0.4536 & $\mathrm{lb}$ & $\mathrm{kg}$ & 2.2046 \\
1.1209 & $\mathrm{lb} / \mathrm{acre}$ & $\mathrm{kg} \cdot \mathrm{ha}^{-1}$ & 0.8922 \\
1 & $\mathrm{ppm}$ & $\mathrm{mg} \cdot \mathrm{L}^{-1}$ & 1 \\
$\left({ }^{\circ} \mathrm{F}-32\right) \div 1.8$ & ${ }^{\circ} \mathrm{F}$ & ${ }^{\circ} \mathrm{C}$ & $\left({ }^{\circ} \mathrm{C} \times 1.8\right)+32$
\end{tabular}


of soluble $\mathrm{N}$ after planting would likely pair nutrient availability with periods of maximum dry matter accumulation in cabbage, which may increase NUE (Barrett et al., 2018). Therefore, states such as Georgia and Florida with sandy soils recommend split applications of fertilizer in cabbage (Granberry et al., 2017; Liu et al., 2019).

Recent studies have shown total yields for cabbage can be maintained by using current $\mathrm{N}$ fertilizer recommendations for Georgia (da Silva et al., 2020a). However, there is little information on how $\mathrm{N}$ source and application frequency may influence $\mathrm{N}$ requirements for growing bareground (without plastic mulch) cabbage in southern Georgia. The objectives of this study were to determine how two fertilization programs applied at a range of $\mathrm{N}$ levels influence development, yield, and nutrient content of fresh market cabbage grown in a bareground production system in Georgia.

\section{Materials and methods}

The study was conducted at The University of Georgia Horticulture Farm in Tifton, GA (lat. $31^{\circ} 5^{\prime} \mathrm{N}$, long. $83^{\circ} 5^{\prime} \mathrm{W}$ ) in Fall 2016 and 2017. The soil in the field (5\% to $8 \%$ slope) was a mix of a Tift sandy loam (10\%) and Carnegie sandy loam (90\%) (U.S. Department of Agriculture, 1983). The same field was used for both planting seasons, but plot locations differed according to year. Before planting, soil $\mathrm{pH}$ ranged from 6.8 to 7.0 , with an average of 87,106 , and $958 \mathrm{lb} /$ acre of phosphorous $(\mathrm{P})$, potassium $(\mathrm{K})$, and calcium $(\mathrm{Ca})$, respectively (Mehlich 3 extract; Waters Agricultural Laboratory, Camilla, GA). Soil test results from both years indicated adequate, medium, and high supplies of $\mathrm{P}, \mathrm{K}$, and $\mathrm{Ca}$, respectively. In 2016, soil organic matter, measured before planting, was $0.44 \%$ (Waters Agricultural Laboratory). Seed of 'Cheers' cabbage (American Takii, Salinas, CA) were sown into 200-cell trays (Speedling, Ruskin, FL) filled with soilless media (Pro-Mix BX; Premier Tech, Quakertown, PA). Seedlings were greenhouse-grown at temperature set points of $88 / 64{ }^{\circ} \mathrm{F}$ (day/night). Plants were watered twice daily as needed and fertilized three times weekly after germination with a $150 \mathrm{mg} \cdot \mathrm{L}^{-1} \mathrm{~N}$ solution $(20 \mathrm{~N}-4.4 \mathrm{P}-16.6 \mathrm{~K}$; Scotts, Marysville, $\mathrm{OH})$.
Plots were harrowed to a depth of $\approx 10$ inches, followed by secondary tillage using a field cultivator (Kelley Manufacturing Co., Tifton, GA). After initial tillage and $3 \mathrm{~d}$ before planting, a preplant homogenized $5 \mathrm{~N}-4.4 \mathrm{P}-12.5 \mathrm{~K}$ fertilizer (Rainbow Plant Food; Agrium, Tifton, GA) at $50 \mathrm{lb} /$ acre N was placed in the rows using a banded fertilizer applicator (First Products, Tifton, GA). Immediately after fertilization, $0.5 \mathrm{lb} /$ acre trifluralin herbicide (Treflan 4L; Corteva Agriscience, Wilmington, DE) was applied and incorporated into the soil with preplant fertilizer using tractormounted rototiller to a depth of 4 inches. After incorporation of preplant fertilizer and trifluralin herbicide, $0.25 \mathrm{lb} /$ acre oxyfluorfen herbicide (Goal 2XL, Corteva Agriscience) was applied to the prepared plant bed and left undisturbed until planting. Sixweek-old cabbage seedings were transplanted on 13 Sept. 2016 and 22 Sept. 2017 into rows spaced 36 inches apart. Within-row spacing was 12 inches. Plots were $6 \mathrm{ft}$ wide and contained two rows of cabbage plants. Plots contained 50 plants ( $25 \mathrm{ft}$ long) and 40 plants $(20 \mathrm{ft}$ long) in 2016 and 2017, respectively. Approximately $10-\mathrm{ft}$ nonplanted buffers were present between adjacent plots within a row. Plants were overheadwatered immediately after planting using solid set sprinkler irrigation (100 Series Big Gun; Nelson Irrigation, Walla Walla, WA). Sprinkler heads were spaced $\approx 100 \mathrm{ft}$ apart, with a watering radius of $100 \mathrm{ft}$.

A two-factorial experimental design using fertilizer source and $\mathrm{N}$ rate was arranged in a randomized, complete block design with three and four replicates in 2016 and 2017, respectively. Treatments consisted of $27 \mathrm{~N}-0 \mathrm{P}-0 \mathrm{~K}-5 \mathrm{Ca}$ granular fertilizer (Ty Ty Peanut Co., Ty Ty, GA) or $9 \mathrm{~N}-0 \mathrm{P}-0 \mathrm{~K}-11 \mathrm{Ca}$ liquid fertilizer (CN9; Big Bend Supply Co., Cairo, GA). The granular $27 \mathrm{~N}-0 \mathrm{P}-0 \mathrm{~K}-5 \mathrm{Ca}$ contained $\approx 13.5 \%$ ammonium and $13.5 \%$ nitrate forms of $\mathrm{N}$, whereas the $9 \mathrm{~N}-0 \mathrm{P}-0 \mathrm{~K}-11 \mathrm{Ca}$ fertilizer contained $7.4 \%$ nitrate $-\mathrm{N}, 0.8 \%$ ammonium $\mathrm{N}$, and $0.6 \%$ urea- $\mathrm{N}(8.8 \% \mathrm{~N})$ (Waters Agricultural Laboratory). The $\mathrm{N}$ rate treatments consisted of season total applications of 175,200 , 225 , and $250 \mathrm{lb} /$ acre $\mathrm{N}$.

In both years, the granular fertilizer was applied by hand in two side- dress applications at $\approx 3$ to 4 weeks and 7 to 8 weeks after planting in accordance with current recommendations for cabbage in the Coastal Plain of Georgia (Kissel and Sonon, 2008). For each side-dress application, $62.5,75,87.5$, and $100 \mathrm{lb} /$ acre $\mathrm{N}$ of granular fertilizer were banded on the soil surface $\approx 6$ inches adjacent to the planted rows. The liquid $9 \mathrm{~N}-0 \mathrm{P}-0 \mathrm{~K}-1 \mathrm{lCa}$ fertilizer was applied as a band $\approx 6$-inches from the planted rows every 7 to $10 \mathrm{~d}$ starting 4 weeks after planting. A total of six liquid fertilizer applications were performed by hand, with each application containing $21,25,29$, and $33 \mathrm{lb} /$ acre $\mathrm{N}$. In the granular fertilizer program $(5.0 \% \mathrm{Ca})$, the $175,200,225$, and $250 \mathrm{lb} /$ acre $\mathrm{N}$ treatments received $24,28,33$, and 38 $\mathrm{lb} /$ acre $\mathrm{Ca}$, respectively, through the additional side-dress applications. In plots receiving the liquid fertilizer $(11 \% \mathrm{Ca}), \approx 152,183,214$, and 244 $\mathrm{lb} /$ acre Ca were applied to the treatments receiving $175,200,225$, and $250 \mathrm{lb} /$ acre $\mathrm{N}$, respectively.

Once established, all plots were overhead-watered with sprinkler irrigation equally to supply $\approx 1$-inch of water per week in two or three applications based on current recommendations for cabbage grown in Georgia (Tyson and Harrison, 2017). Rainfall was monitored by an on-farm weather station from The University of Georgia Weather Network [Tifton Station, Tifton, GA (University of Georgia, 2021)] and irrigation was adjusted accordingly. Maximum, minimum, and daily average air temperatures were recorded and the daily growing degree days (GDD) after transplanting were calculated by averaging the daily maximum and minimum air temperatures and then subtracting the minimum base temperature of $50{ }^{\circ} \mathrm{F}$ (Isenberg et al., 1975). Cumulative GDD were calculated after removing days when GDD were negative. Because air temperatures more than $30^{\circ} \mathrm{C}\left(86.0^{\circ} \mathrm{F}\right)$ have been reported to decrease yield of cabbage (Warland et al., 2006), GDD calculations were also conducted using a maximum temperature of $86^{\circ} \mathrm{F}$.

Fungicides and insecticides were applied weekly according to commercial recommendations for cabbage grown in Georgia (Horton, 2016). Cabbage foliar nutrient concentrations were determined at the first harvest by taking one fully expanded inner wrapper leaf 
from 10 representative plants in each plot (Bryson et al., 2014). Leaves were briefly rinsed with distilled water, and each sample was oven-dried at $65^{\circ} \mathrm{C}$ for $7 \mathrm{~d}$. Samples were analyzed for $\mathrm{N}$, $\mathrm{P}, \mathrm{K}, \mathrm{Ca}$, magnesium $(\mathrm{Mg})$, and sulfur (S) by a commercial laboratory (Waters Agricultural Laboratory).

Cabbage plants were harvested when they reached a marketable size at $69,86,98$, and $113 \mathrm{~d}$ after planting in 2016, and at 80,88 , and $102 \mathrm{~d}$ after planting in 2017. Nearly all heads were harvested when they reached a medium size $(>3.0 \mathrm{lb})$ according to U.S. Department of Agriculture grade standards for grades of fresh market cabbage (U.S. Department of Agriculture, 2016). A limited number of nonmarketable heads were left in the field. Wrapper (outer) leaves were removed, and harvested heads were counted and weighed at harvest. Yields of the first two harvests were considered "early yield." Nitrogen use efficiency was determined by dividing the total marketable yield (fresh weight) by the amount of $\mathrm{N}$ applied for the season.

Data were analyzed using the linear mixed model as implemented in SAS PROC GLIMMIX (version 9.4; SAS Institute, Cary, NC). Total and early yield data were subjected to linear regression analysis using $\mathrm{N}$ fertilization rate as the independent variable $(P<0.05)$. Data were analyzed for the presence of significant main effects and interactions. When interactions were not present, data main effects were analyzed. Least-square means (LS means) comparisons were performed using Fisher's least significant difference test $(P<0.05)$.

\section{Results and discussion}

In general, the 2016 growing season was warmer than 2017 (Table 1). The average high air temperature was $4.4^{\circ} \mathrm{F}$ greater during the growing season in 2016 compared with 2017, resulting in the accumulation of 1729 GDD in 2016 compared with 1340 GDD in 2017 (Isenberg et al., 1975). When temperatures higher than $86^{\circ} \mathrm{F}$ were excluded, there were 1705 GDD and 1316 GDD in 2016 and 2017, respectively, for the entire production season (data not shown). Average daily high temperatures during the final month (harvest period) of the growing season were nearly $7{ }^{\circ} \mathrm{F}$ greater in
2016 than in 2017 (data not shown). The increased GDD in 2016 corresponded to a first harvest at $69 \mathrm{~d}$ after transplanting compared with $80 \mathrm{~d}$ after transplanting in 2017. Rainfall totaled 13.21 and 6.48 inches during the 2016 and 2017 growing seasons, respectively. Although there was more than twice as much total rainfall in 2016, there were only 0.91 inches of rain between transplanting and the first harvest, suggesting that much of the growing season was dry. More than half of the rain for the growing season occurred in a single event of 6.95 inches on 4 and 5 Dec. 2016. In contrast, rainfall during 2017 was distributed throughout the growing season, with $\approx 85 \%$ of rainfall occurring between transplanting and first harvest (data not shown). Air temperatures higher than $30^{\circ} \mathrm{C} \quad\left(86.0^{\circ} \mathrm{F}\right)$ for extended periods of time have been reported to decrease the yield of cabbage (Warland et al., 2006). In 2016, maximum air temperatures regularly exceeded $86{ }^{\circ} \mathrm{F}$ through the end of October.

There were no interactions among year, $\mathrm{N}$ fertilizer level, or fertilizer type for total and early cabbage yields, head weight, and NUE. The main effects of fertilizer source and $\mathrm{N}$ rate had no impact on total cabbage yield and head weight; however, year significantly affected total cabbage yield and head weight (Table 2). Total marketable yields were significantly greater in $2016(58,710 \mathrm{lb} / \mathrm{acre})$ compared with those in 2017 (47,800 lb/acre). Similarly, average head weight was higher in $2016(3.43 \mathrm{lb})$ compared with 2017 $(3.10 \mathrm{lb})$. Despite greater total yields in 2016 than 2017, and greater accumulation of GDD, cabbage early yield (first two harvests) was greater in 2017. Early yields were $29,180 \mathrm{lb} /$ acre in 2017 and $25,370 \mathrm{lb} /$ acre in 2016 . If quality is maintained, then an earlier harvest is advantageous to growers. Reducing the time that a cabbage crop

Table 1 . The average daily maximum $\left(T_{\max }\right)$ and minimum $\left(T_{\min }\right)$ temperatures, accumulated rainfall, and growing degree day units (GDD) at the trial location for cabbage grown at Tifton, GA, in Fall 2016 and 2017.

\begin{tabular}{|c|c|c|c|c|c|}
\hline \multirow[b]{2}{*}{$\underline{\text { Yr }}$} & $\underline{\mathrm{T}_{\max }}$ & $\mathrm{T}_{\min }$ & \multirow[b]{2}{*}{ Rainfall (inches) $^{\mathrm{z}}$} & $\underline{\text { First harvest }}$ & Final harvest \\
\hline & & & & \multicolumn{2}{|c|}{$\mathrm{GDD}^{\mathrm{y}}$} \\
\hline 2016 & 76.3 & 53.4 & 13.21 & 1356 & 1729 \\
\hline 2017 & 71.9 & 51.5 & 6.48 & 1239 & 1340 \\
\hline
\end{tabular}

is in the field may reduce inputs as well as the impact of pathogens such as Sclerotinia sclerotiorum, which can thrive under temperatures encountered during November and early December in southern Georgia (Krishnamoorthy et al., 2017). Black rot, caused by Xanthomonas campestris pv. Campestris, also has the potential to cause significant losses of fall-grown cabbage in Georgia (da Silva et al., 2020b). Lower early yields in 2016 could be a result of supraoptimal air temperatures that reduced negatively impacted cabbage filling out (internal density) during October (McKeown et al., 2010; Warland et al., 2006). However, higher total yields for the entire season in 2016 may be the result of continued accumulation of GDD during the harvest period in December (Table 1). Furthermore, Kleinhenz and Wszelaki (2003) reported that variable air temperatures during development could significantly influence yield of 'Cheers' cabbage grown in Ohio. Rainfall, air temperature, and light levels, which vary among growing seasons, have been documented to influence yield and maturity of cabbage (Barrett et al., 2015; Isenberg et al., 1975; McKeown et al., 2010). Because fertilizer source and $N$ rates were identical in both years, NUE decreased in 2017 compared with 2016 due to the lower yields obtained in 2017 (Table 2). Similarly, Barrett et al. (2018) reported differences in NUE over multiple seasons for cabbage grown in Florida.

The total marketable yield was not impacted by $\mathrm{N}$ fertilization level (Table 2). Yields for all $\mathrm{N}$ treatments averaged 52,480 lb/acre (data not shown). In addition, linear regression evaluating the effects of $\mathrm{N}$ fertilization level on total marketable yield was not significant $(P<0.05)$ (data not shown). Marketable yields were higher than those typical for commercial growers in the region (Fonsah, 2021), but they were comparable to those in 
Table 2. Main effects of nitrogen $(\mathrm{N})$ rate, fertilizer program, and year on total yield, yield of first two harvests (early yield), average head weight, and nitrogen use efficiency (NUE) for cabbage grown at Tifton, GA in Fall 2016 and 2017.

\begin{tabular}{|c|c|c|c|c|c|c|c|c|}
\hline & Total yiel & & Early yie & & \multirow{2}{*}{\multicolumn{2}{|c|}{$\begin{array}{c}\text { Head } \\
\text { wt }(\mathbf{l b})^{z}\end{array}$}} & \multirow{2}{*}{\multicolumn{2}{|c|}{$\begin{array}{c}\mathrm{NUE}^{\mathrm{y}} \\
(\mathrm{lb} \text { yield/lb } \mathrm{N})\end{array}$}} \\
\hline & \multicolumn{4}{|c|}{ (lb/acre) } & & & & \\
\hline \multicolumn{9}{|c|}{$\mathrm{N}$ rate $(\mathrm{lb} / \mathrm{acre})^{\mathrm{z}}$} \\
\hline 175 & 52,080 & $a^{x}$ & 21,820 & $\mathrm{~b}$ & 3.19 & $\mathrm{a}$ & 298 & a \\
\hline 200 & 52,800 & $\mathrm{a}$ & 28,760 & $\mathrm{a}$ & 3.26 & $\mathrm{a}$ & 264 & $\mathrm{~b}$ \\
\hline 225 & 51,030 & $\mathrm{a}$ & 29,490 & $\mathrm{a}$ & 3.23 & $\mathrm{a}$ & 227 & $\mathrm{c}$ \\
\hline 250 & 53,990 & $\mathrm{a}$ & 30,470 & $\mathrm{a}$ & 3.30 & $\mathrm{a}$ & 216 & $\mathrm{c}$ \\
\hline \multicolumn{9}{|c|}{ Fertilizer program ${ }^{\mathrm{w}}$} \\
\hline Liquid & 58,970 & $\mathrm{a}$ & 32,040 & $\mathrm{a}$ & 3.23 & $\mathrm{a}$ & 252 & a \\
\hline Granular & 58,580 & $\mathrm{a}$ & 29,790 & $\mathrm{a}$ & 3.23 & $\mathrm{a}$ & 250 & a \\
\hline \multicolumn{9}{|l|}{ Year } \\
\hline 2016 & 58,710 & $\mathrm{a}$ & 25,370 & $\mathrm{~b}$ & 3.43 & $\mathrm{a}$ & 281 & a \\
\hline 2017 & 47,800 & $\mathrm{~b}$ & 29,180 & $\mathrm{a}$ & 3.10 & $\mathrm{~b}$ & 227 & $\mathrm{~b}$ \\
\hline
\end{tabular}

${ }^{\mathrm{z}} \mathrm{l} \mathrm{lb} / \mathrm{acre}=1.1209 \mathrm{~kg} \cdot \mathrm{ha}^{-1}, \mathrm{l} \mathrm{lb}=0.4536 \mathrm{~kg}$.

${ }^{\mathrm{y}}$ NUE based on fresh weight of total yield divided by $\mathrm{N}$ applied.

${ }^{\mathrm{x}}$ Values in the same column and treatment group followed by the same letter(s) are not significantly different at $P \leq 0.05$ according to Fisher's least significant difference test.

${ }^{\mathrm{w}} \mathrm{Liquid}$ fertilizer program $(9 \mathrm{~N}-0 \mathrm{P}-0 \mathrm{~K}-1 \mathrm{Ca})$ and granular fertilizer program $(27 \mathrm{~N}-0 \mathrm{P}-0 \mathrm{~K}-5.1 \mathrm{Ca})$.

prior studies (Coolong and Roberts, 2014). Recently, da Silva et al. (2020a) evaluated the impact of $\mathrm{N}$ fertilizer rates from 170 to $280 \mathrm{lb} /$ acre N on cabbage grown in Georgia and Florida. Although no effects of fertilizer rate on cabbage yield were reported in Georgia, yield for cabbage grown in Florida increased when $225 \mathrm{lb} /$ acre N was applied to the crop compared with $170 \mathrm{lb} /$ acre $\mathrm{N}$. In the present study, $\mathrm{N}$ rate did not affect total cabbage yields; however, it did impact the early yields (first two harvests). Early yields were $21,820 \mathrm{lb} /$ acre for cabbage grown with $175 \mathrm{lb} /$ acre $\mathrm{N}$, which was lower than that of cabbage grown with higher $\mathrm{N}$ rates (Table 2). There were no differences in early yields among cabbage grown with 200,225 , or $250 \mathrm{lb} / \mathrm{acre} \mathrm{N}$. A linear regression was conducted to compare $\mathrm{N}$ fertilization levels for their impact on early yield. Although significant, the coefficient of determination was low $(\mathrm{y}=4756+$ $\left.107.8 \mathrm{~N} ; R^{2}=0.14\right)$. As noted previously, a delay in harvest for cabbage is undesirable for growers in the region because it can lead to additional input costs and a greater risk loss caused by diseases, which can result in significant losses for growers in Georgia (Little, 2019). Increasing $\mathrm{N}$ fertilization previously has been reported to reduce days to maturity in trials conducted in Ontario, Canada (Westerveld et al., 2003). Although total cabbage yields were unaffected by $\mathrm{N}$ fertilization rate, the $175 \mathrm{lb} /$ acre application resulted in a delay in maturity.

Because total cabbage yields did not differ between $\mathrm{N}$ treatments, NUE decreased as $\mathrm{N}$ fertilization increased (Table 2). Applying $175 \mathrm{lb} /$ acre N resulted in an NUE of $298 \mathrm{lb}$ cabbage/lb $\mathrm{N}$, which was greater than that of all other treatments. The lowest NUEs were observed for plots receiving 225 and $250 \mathrm{lb} /$ acre $\mathrm{N}$, with NUEs of 227 and $216 \mathrm{lb}$ cabbage per pound $\mathrm{N}$, respectively. The NUE results are similar to those obtained by Barrett et al. (2018) for cabbage grown with $175 \mathrm{lb} /$ acre $\mathrm{N}$ in Florida using a plasticulture system.

Yields for cabbage grown with the liquid and granular programs were 58,970 and $58,580 \mathrm{lb} /$ acre, respectively (Table 2). Early yields and average head weights were unaffected by the fertilizer program (Table 2). Current fertilization recommendations for bare-ground cabbage in Georgia suggest that $\mathrm{N}$ applied after planting should be split into two applications $\approx 3$ to 8 weeks after transplant (Granberry et al., 2017; Kissel and Sonon, 2008). Because of costs, granular fertilizers are most often used. However, more cabbage is now being grown using plasticulture in the southeastern United States, where highly soluble N sources are applied through drip irrigation (Barrett et al., 2015, 2018). Growers in Georgia have begun using frequent applications of soluble liquid fertilizers in bare-ground production systems to increase yields and reduce potential $\mathrm{N}$ losses. However, in the present study, frequent applications of a liquid fertilizer (calcium nitratebased) to cabbage throughout the growing season did not affect NUE or yields compared with the two larger applications of a granular product. Seeding cool season cereal crops after harvest could help reduce further losses of residual $\mathrm{N}$ after the fall cabbage growing season (Thapa et al., 2018).

There were no interactions among year, $\mathrm{N}$ rate, or fertilizer source for foliar macronutrient concentrations. When treatment main effects were analyzed, fertilizer source and year affected the concentration of foliar nutrient concentrations (Table 3). Nitrogen fertilizer rate did not impact foliar macronutrient concentrations (data not shown). When fertilizer programs were compared, there were no differences in $\mathrm{N}(3.65 \%), \mathrm{P}(0.37 \%), \mathrm{K}(3.45 \%), \mathrm{Mg}$ $(0.33 \%)$, and $S(1.19 \%)$ in the liquid and granular fertilizer programs. Nutrient concentrations were within normal ranges for macronutrients, apart from $S$, which was found at a higher range than is typically reported (Bryson et al., 2014). Elevated S levels were not observed to be problematic and further, $S$ has been found to be essential in head formation of cabbage with $S$ containing glucosinolates prevalent in a variety of cole crops [Brassica sp. (Hara and Sonoda, 1981; McKeown and Bakker, 2003)]. However, fertilizer source affected foliar Ca concentrations. Plants receiving liquid fertilizer had foliar Ca values of $1.93 \%$, whereas those treated with the two granular fertilizer applications had $\mathrm{Ca}$ values of $1.80 \%$. Because the liquid fertilizer program contained between 128 and 206 $\mathrm{lb} /$ acre additional $\mathrm{Ca}$ than the granular fertilizer program, it would be expected that those plants treated with the liquid fertilizer program would accumulate more $\mathrm{Ca}$. Additional $\mathrm{Ca}$ has been reported to increase cabbage yields and reduce risks from disorders such as internal tip burn (Everaarts and BlomZandstra, 2001; McKeown and Bakker, 2003). Nonetheless, there were no yield differences among the fertilizer programs, and no diseases or disorders were observed in the study. Although differences in foliar $\mathrm{Ca}$ were observed between the two fertilizer programs, 
Table 3. Foliar concentrations of nitrogen $(\mathrm{N})$, phosphorous $(\mathrm{P})$, potassium $(\mathrm{K})$, calcium $(\mathrm{Ca})$, magnesium $(\mathrm{Mg})$, and sulfur $(S)$ in cabbage grown with supplemental liquid calcium nitrate or granular fertilizer in Fall 2016 and 2017.

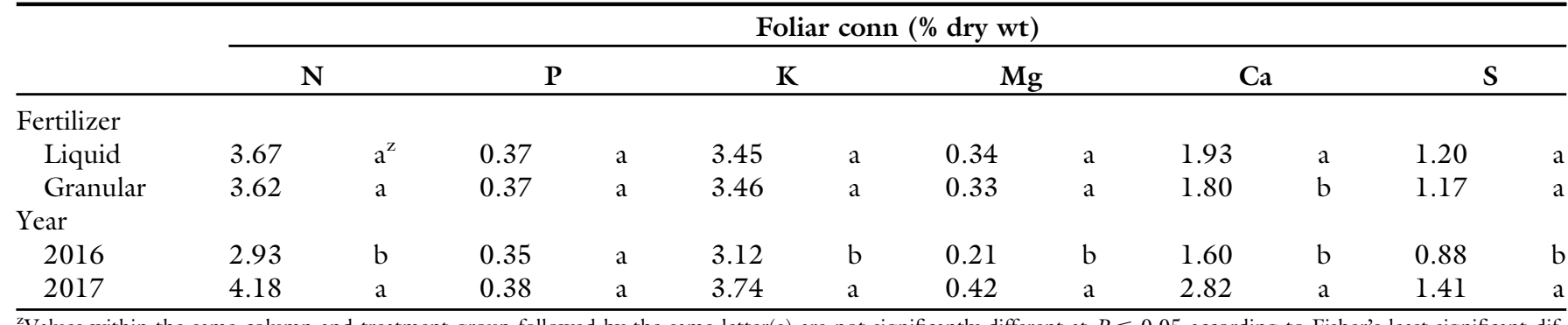

${ }^{\mathrm{z}}$ Values within the same column and treatment group followed by the same letter(s) are not significantly different at $P \leq 0.05$ according to Fisher's least significant difference test.

they likely did not affect the overall results of the study.

There were significant effects of the study year on foliar macronutrient concentrations (Table 3). Foliar concentrations of $\mathrm{N}, \mathrm{K}, \mathrm{Mg}, \mathrm{Ca}$, and $\mathrm{S}$ were greater in 2017 compared with 2016, whereas concentrations of $\mathrm{P}$ were unchanged among the studied years. Nitrogen concentrations were $2.93 \%$ and $4.18 \%$ in 2016 and 2017, respectively. Similarly, foliar K levels increased from $3.12 \%$ in 2016 to $3.74 \%$ in 2017 . Foliar $\mathrm{Mg}$ concentrations doubled in $2017(0.42 \%)$ compared with those in $2016(0.21 \%)$. Foliar Ca concentrations were adequate to high in $2016(1.60 \%)$, and they were higher in $2017(2.82 \%)$ (Bryson et al., 2014). The same field was used in both study years, and no significant fertilizer applications were performed on the plots between the 2016 and 2017 seasons that would account for increased nutrient availability in 2017. Furthermore, preplant soil tests showed no notable differences between study years. Differences in nutrient uptake during the studied years were not unexpected. Previously, $\mathrm{N}$ uptake in cabbage was shown to be significantly influenced by temperature and decreased above $20^{\circ} \mathrm{C}$ (Hara and Sonoda, 1982). Furthermore, nutrient concentrations in a related crop, collards (Brassica oleracea var. acephala), have also been reported to vary significantly according to growing season (Mylavarapu et al., 2005). Increased nutrient concentrations in 2017 did not correspond to an increased head size or total yield.

\section{Conclusions}

Total $\mathrm{N}$ requirements for bareground cabbage grown in the southeastern United States have recently been studied (da Silva et al., 2020a). However, $\mathrm{N}$ source and timing of application have not been previously evaluated for impact on yield, development rate, or nutrient content in cabbage. The present study sought to determine the advantage (if any) of increasing the frequency of $\mathrm{N}$ fertilization with a soluble $\mathrm{N}$ source for cabbage production in Georgia. Fertilizer source and timing did not impact yield in the present study. Although we found no impact of $\mathrm{N}$ rate on total yield, data suggest that growing cabbage at the lowest recommended rate $(175 \mathrm{lb} /$ acre $\mathrm{N})$ leads to later development and a lower early yield for growers. Prior studies may not report timing of harvest, but because there is value in reducing the time that cabbage is in the field, it would be recommended to use a minimum of 200 $\mathrm{lb} / \mathrm{acre} \mathrm{N}$ to grow cabbage in the Coastal Plain region of Georgia. In addition, data suggest levels more than $200 \mathrm{lb} /$ acre $\mathrm{N}$ may not be needed to produce a commercially acceptable yield for fresh market cabbage. Furthermore, current recommended fertilizer application methods were equivalent to multiple applications of highly soluble fertilizers for maintaining cabbage productivity.

\section{Literature cited}

Barrett, C.E., L. Zotarelli, L.G. Paranhos, P. Dittmer, C.W. Fraisse, and J. VanSickle. 2015. Optimum planting configuration for high population plasticulture grown cabbage. HortScience 50:1472-1478, https://doi.org/10.21273/HORTSCI.50. 10.1472 .

Barrett, C.E., L. Zotarelli, L.G. Paranhos, P. Dittmer, C.W. Fraisse, and J. VanSickle. 2018. Optimization of irrigation and Nfertilizer strategies for cabbage plasticulture system. Scientia Hort. 234:323-334, https://doi.org/10.1016/j.scienta.2018. 02.063 .

Bryson, G.M., H.A. Mills, D.N. Sasseville, J.B. Jones, and A.V. Barker. 2014. Plant analysis handbook III. Micro Macro Publ., Athens, GA.

Coolong, T. and M. Roberts. 2014. Fall planted cabbage variety trials in southwest Georgia. HortScience 49:S59 (Abstr.), https://doi.org/10.21273/HORTSCI.49. 9S.S1.

da Silva, A.L.B.R., J.S. Candian, L. Zotarelli, T. Coolong, and C. Christensen. 2020a. Nitrogen fertilizer management and cultivar selection for cabbage production in the southeastern United States. HortTechnology 30:685-691, https://doi. org/10.21273/HORTTECH04690-20.

da Silva, A.L.B.R., J.S. Candian, E.R. do Rego, T. Coolong, and B. Dutta. 2020b. Screening cabbage cultivars for resistance to black rot under field conditions. HortTechnology 30:448-455, https://doi.org/ 10.21273/HORTTECH04481-19.

Delgado, J.A. 2002. Quantifying the loss mechanisms of nitrogen. J. Soil Water Conserv. 57:389-398.

Everaarts, A.P. 1993. Strategies to improve the efficiency of nitrogen fertilizer use in the cultivation of Brassica vegetables. Acta Hort.339:161-173, https://doi.org/ 10.17660/ActaHortic.1993.339.14.

Everaarts, A.P. and M. Blom-Zandstra. 2001. Internal tipburn of cabbage (Brassica oleracea var. capitata). J. Hort. Sci. Biotechnol. 76:522-528, https://doi.org/ 10.1080/14620316.2001.11511402.

Fonsah, E.G. 2021. Cabbage - Bareground and irrigated budget. 15 Sept. 2021. $<$ https://agecon.uga.edu/extension/bud gets.html>.

Granberry, D., W.T. Kelly, and G. Boyhan. 2017. Soil and fertilizer management, p. 8-12. In: T. Coolong (ed.). Commercial production and management of cabbage and leafy greens. Univ. Georgia Coop. Ext. Serv. Bul. 1181. 
Hara, T. and Y. Sonoda. 1981. The role of macronutrients in cabbage-head formation. Soil Sci. Plant Nutr. 27:45-54, https://doi.org/10.1080/00380768.1981. 10431253.

Hara, T. and Y. Sonoda. 1982. Cabbage head development as affected by nitrogen and temperature. Soil Sci. Plant Nutr. 28:109-117, https://doi.org/10.1080/ 00380768.1982.10432376.

Hartz, T.K. 2006. Vegetable production best management practices to minimize nutrient loss. HortTechnology 16:398-403, https://doi.org/10.21273/HORTTECH. 16.3.0398.

Horton, D. 2016. 2016 Georgia pest management handbook. Univ. Georgia Coop. Ext. Serv. Spec. Bul. 28.

Isenberg, F.M.R., A. Pendergress, J.E. Carroll, L. Howell, and E.B. Oyer. 1975. The use of weight, density, heat units, and solar radiation to predict the maturity of cabbage for storage. J. Amer. Soc. Hort. Sci. 100:313-316.

Kissel, D.E. and L. Sonon. 2008. Soil test handbook for Georgia. Univ. Georgia Coop. Ext. Serv. Spec. Bul. 62.

Kleinhenz, M.D. and A. Wszelaki. 2003. Yield and relationships among head traits in cabbage as influenced by planting date and cultivar. I. Fresh market. HortScience 38:1349-1354, https://doi.org/10.21273/ HORTSCI.38.7.1349.

Krishnamoorthy, K.K., A. Sankaralingam, and S. Nakkeeran. 2017. Effect of temperature and salinity on the growth of Sclerotinia sclerotiorum causing head rot of cabbage. Int. J. Curr. Microbiol. Appl. Sci. 6:950-954, https://doi.org/10.20546/ ijcmas.2017.602.106.
Lamont, W.J. 1993. Plastic mulches for the production of vegetable crops. HortTechnology 3:35-39, https://doi.org/ 10.21273/HORTTECH.3.1.35.

Little, E.L.2019. 2016 Georgia plant disease loss estimates. Univ. Georgia Coop. Ext. Serv. Bul. AP 102-9.

Liu, G.D., E.H. Simonne, K.T. Morgan, G.J. Jochmuth, S. Agehara, and R. Mylavarapu. 2019. Fertilizer management for vegetable production in Florida, p. 3-9. In: P.J. Dittmar (ed.). Vegetable production handbook of Florida 2019-2020. Univ. Florida IFAS Ext. Bul. CV292.

McKeown, A.W. and C.J. Bakker. 2003. The response of late storage cabbage and broccoli to applications of sulphur and calcium. Can. J. Plant Sci. 83:947-950, https://doi.org/10.4141 /P02-068.

McKeown, A.W., S.M. Westerveld, and C.J. Bakker. 2010. Nitrogen and water requirements of fertigated cabbage in Ontario. Can. J. Plant Sci. 90:101-109, https://doi.org/10.4141/CJPS09028.

Mylavarapu, R.S., J.P. Smith, and F. Munoz. 2005. Influence of soil and nutrient management on growth and quality of collards. HortTechnology 6:163-168, https://doi.org/10.21273/HORTTECH. 15.1 .0163

Salo, T., T. Suojala, and M. Kallela. 2002. The effect of fertigation on yield and nutrient uptake of cabbage, carrot, and onion. Acta Hort.571:235-241, https://doi. org/10.17660/ActaHortic.2002.571.28.

Scholberg, J.M.S., L. Zotarelli, M.D. Dukes, M. Ozores-Hampton, and G.D. Liu. 2013. Enhancing fertilizer efficiency in high input cropping systems in Florida.
Sustain. Agr. Res. 12:143-174, https:// doi.org/10.1007/978-94-007-5961-9_5.

Stubbs, K.2020. 2019 Georgia farm gate value report. Univ. Georgia Coop. Ext. Serv. Bul. AR-20-01

Thapa, R., S. Mirsky, and K. Tully. 2018. Cover crops reduce nitrate leaching in agroecosystems: A global meta-analysis. J. Environ. Qual. 47:1400-1411, https:// doi.org/10.2134/jeq2018.03.0107.

Tyson, A. and K. Harrison. 2017. Irrigation, p. 31. In: T. Coolong (ed.). Commercial production and management of cabbage and leafy greens. Univ. Georgia Coop. Ext. Serv. Bul. 1181.

University of Georgia. 2021. Tifton, Georgia climate data. 8 Sept. 2021. <http://www. georgiaweather.net/?content $=$ calculator $\&$ variable $=\mathrm{CC} \&$ site $=$ TIFTON $>$.

U.S. Department of Agriculture. 1983. Soil survey. Web soil survey - Soil survey of Tift County, Georgia. 23 Aug. 2021. <https://websoilsurvey.sc.egov.usda.gov/ App/WebSoilSurvey.aspx $>$.

U.S. Department of Agriculture. 2016. United States standards for grades of cabbage. U.S. Dept. Agr., Washington, DC.

Warland, J., A.W. McKeown, and M.R. McDonald. 2006. Impact of high air temperatures on Brassicaceae crops in southern Ontario. Can. J. Plant Sci. 86:1209-1215, https://doi.org/10.4141/P05-067.

Westerveld, S.M., M.R. McDonald, A.W McKeown, and C.D. Scott-Dupree. 2003. Optimum nitrogen fertilization of summer cabbage in Ontario. Acta Hort.627:211-215, https://doi.org/10.17 660/ActaHortic.2003.627.27. 